ГORIGINAL ARTICLE

Volume 16 Supp 12021

DOI: 10.21315/aos2021.16.s1.4

ARTICLE INFO

Submitted: 02/03/2021

Accepted: 27/05/2021

Online: $22 / 09 / 2021$

\section{Acanthus ilicifolius L. Treatment for Oral Candidiasis with Immunosuppressive Conditions Subjected to p38 MAPK Enhancement}

\author{
Dwi Andriani*, Agni Febrina Pargaputri, Kristanti Parisihni, Syamsulina \\ Revianti
}

Department of Oral Biology, Faculty of Dentistry, Universitas Hang
Tuah Surabaya, Kota Surabaya, fawa Timur 60111, Indonesia
*Corresponding author: dwi.andriani@hangtuah.ac.id

To cite this article: Andriani D, Pargaputri AF, Parisihni K, Revianti S (2021). Acanthus ilicifolius L. treatment for oral candidiasis with immunosuppressive conditions subjected to p38 MAPK enhancement. Arch Orofac Sci, 16(Supp.1): 17-24. https://doi.org/10.21315/aos2021.16.s1.4

To link to this article: https://doi.org/10.21315/aos2021.16.s1.4

\begin{abstract}
Methanolic extract from the leaves of Acanthus ilicifolius L. (A. ilicifolius L.) is a potent inhibitor of Candida albicans (C. albicans) growth and anti-inflammatory. C. albicans causes oral candidiasis in immunosuppressive condition. Mitogen-activated protein kinase (MAPK) signalling via p38 appears to discriminate between yeast and hyphal cells of C. albicans. Activation of p38 MAPK by hyphae results in the upregulation of proinflammatory cytokines. The p38 MAPK activation is known to impair corticosteroid action. The research was conducted to investigate the effect of methanolic extract $A$. ilicifolius L. treatment of oral candidiasis with the immunosuppressive condition through enhancement of p38 MAPK expression in the epithelial cells. Immunosuppressed conditions were obtained when 16 healthy male Rattus norvergicus (Wistar) was given oral administration of dexamethasone and tetracycline for 14 days and induced with C. albicans (ATCC-10231) 1 McFarland. The subjects were divided into four groups $(n=4 /$ group $)$ : immunosuppression (IS), immunosuppression with oral candidiasis without treatment (ISC), immunosuppression with oral candidiasis and nystatin treatment (ISC+N), and immunosuppression with oral candidiasis and $A$. ilicifolius $\mathrm{L}$. treatment (ISC+AI), and were treated for 14 days. Later, the rats were euthanised, and their tongue were biopsied. The p38 MAPK expression was subjected to immunohistochemical examination, observed under a microscope (400× magnification) and statistically analysed (one-way ANOVA, LSD-test, $p<0.05$ ). The p38 MAPK expression of ISC+AI $(36.05 \pm 1.54)$ was higher than IS $(26 \pm 2.32)$, ISC $(26.4 \pm 3.71)$, IS+N $(34.2 \pm 0.99)$. Significant differences existed between ISC+AI and ISC+N to IS and ISC $(p<0.05)$. No significant differences were present between IS and ISC; ISC+AI and ISC+N $(p>0.05)$. Therefore, this treatment could enhance p38 MAPK expression in oral candidiasis with the immunosuppressed condition.
\end{abstract}

Keywords: Corticosteroid; immunosuppressed condition; nystatin; oral candidiasis; $p 38$ MAPK

\section{INTRODUCTION}

Immunosuppressive drugs are the drugs that suppress the immune system used to prevent the production of antibodies. However, due to their non-selective action, they have various side effects (Kant et al., 2009). Increased risk of opportunistic infections such as fungal infection are associated with these drugs. Oral candidiasis is associated with predisposing factors, which includes the disruption of the oral bacterial community by 
the lengthy use of broad-spectrum antibiotics and any disorder that leads to an impaired immune response (Hebecker et al., 2014). The Candida species is one of the common human fungal pathogens, which are benign commensals of the normal skin and mucosal flora in approximately $80 \%$ of the population (Tang et al., 2016). Among the Candida spp., Candida albicans (C. albicans) ranks first in isolation frequency and morphological flexibility that plays crucial roles in several aspects of infection and host recognition (Brunke \& Hube, 2013; Noble et al., 2017).

The epithelial cells are the crucial firstline barrier as they are constantly exposed to the external environment (Tang et al., 2016). The initial stage of $C$. albicans before colonisation and growth is adhesion to the epithelial cells, which are prerequisites for mucosal candidiasis (Zakikhany et al., 2007; Wächtler et al., 2011). Epithelial cells are capable of discriminating between the $C$. albicans yeast and hyphal form via Mitogen-activated protein kinase (MAPK) signalling pathways and activating immune responses (Moyes et al., 2010). Recognition via specific MAPK of the filamentous form appears to initiate a danger response mechanism constituting MAPK phosphatase 1 (MKP-1) and c-Fos activation which may inform the host of when this normally commensal fungus has become invasive (pathogenic) (Tang et al., 2016). p38 MAPK or c-Fos signalling is only activated by Candida species that form hyphae such as C. albicans and C. dubliniensis, but not by pseudo hypha-forming Candida species such as $C$. tropicalis, C. glabrata, C. parapsilosis and C. krusei (Moyes et al., 2012). Activation of p38 MAPK results c-Fos transcription factor recruitment which play essential roles in the transcription of cytokines secreted by the epithelial cells. This mechanism then leads to the upregulation of cytokines and inflammatory mediators (Naglik \& Moyes, 2011; Moyes \& Naglik, 2011). Anti-inflammation mechanism of corticosteroid works by increasing the synthesis of anti-inflammatory proteins, such as MKP-1 which functions contrary to p38 MAPK (Adcock \& Lane, 2003). The p38 MAPK activation impairs corticosteroid action.

The previous study reported that A. ilicifolius L. leaves extract showed promising effect against $C$. albicans. $A$. ilicifolius $\mathrm{L}$. leaves extract could increase TLR2 and IL-22 expression in oral candidiasis with the immunosuppressive condition (Andriani \& Pargaputri, 2018; Andriani \& Pargaputri, 2019). Methanolic A. ilicifolius L. leaves extract $20 \%$ has the ability to increase macrophages oral candidiasis under the immunosuppressive condition. Macrophages are recognised as the innate immune cells involved in C. albicans infection (Setyawan et al., 2019). A methanol extract of $A$. ilicifolius $\mathrm{L}$. exhibit the highest antioxidant activity than the other solvent extracts and also has the ability in inhibiting C. albicans (Sofia \& Merlee, 2017).

Based on the background above, we show that the activation of p38 MAPK pathways is playing an important role in the inflammation mechanism in oral candidiasis. Immunosuppressive conditions result in a weakening of the immune system. Therefore, this research aim was to determine the effect of methanolic extract $A$. ilicifolius $\mathrm{L}$. treatment for oral candidiasis with the immunosuppressive condition through enhancement of p38 MAPK in epithelial cells.

\section{MATERIALS AND METHODS}

\section{Animal Model}

This was a true experiment with posttest only control group design. Sixteen healthy male Rattus novergicus strain Wistar aged 12 weeks, $200 \mathrm{~g}$ to $250 \mathrm{~g}$ in weight were taken as the animal model for immunosuppressed oral candidiasis, divided into four groups $(n=4 /$ group $)$ of immunosuppression 
(IS), immunosuppression with oral candidiasis without treatment (ISC), immunosuppression with oral candidiasis and nystatin treatment (ISC+N), and immunosuppression with oral candidiasis and A. ilicifolius L. treatment (ISC+AI). Immunosuppression was performed by giving dexamethasone $0.5 \mathrm{mg} /$ day and tetracycline $1 \%$ /day orally for seven days. On 8 th day, we reduced the dose until $10 \%$ for dexamethasone and tetracycline, $1 \%$. On 8 th day, up to 20 rats were induced with $0.1 \mathrm{cc}$ C. albicans ATCC-10231 1 McFarland, applied on the rats' tongues using sterile cotton bud three times a week for two weeks (Chami et al., 2004).

\section{Extract Preparation}

Fresh leaves of the $A$. ilicifolius L. are taken from Wonorejo Mangrove Forest, on the east coast of Surabaya, Indonesia and were identified by the staff from Bioscience and Plant Technology Laboratory, Department of Biology, Institute Technology Sepuluh Nopember, Surabaya. Preparation for A. ilicifolius L. methanolic extraction methods based on Andriani et al. (2020). A. ilicifolius L. methanolic was made of the dried leaves that were ground to a coarse powder. About $1,000 \mathrm{~g}$ of $A$. ilicifolius $\mathrm{L}$. powder was soaked with methanol $98 \%$ in Erlenmeyer flask covered with aluminium foil for 48 hours with occasional shaking and stirring. After that, it was filtered with Whatman's no.1 filter paper. The solvent was then evaporated at low pressure by using a rotary evaporator to get a viscous mass. Then it was evaporated with a water bath to separate the extract from the solvent. The methanolic extract was dissolved in $0.2 \%$ CMCNa to get a concentration of $20 \%$ (Andriani et al., 2020).

\section{Treatment and Examination}

Nystatin as control group was applied on tongue surface, $0.5 \mathrm{cc}$ at the same hours twice a day for 14 days as $A$. ilicifolius L. methanolic extract $20 \%$. After treated for 14 days, the rats in each group were sacrificed and biopsied. The p38 MAPK expression was examined using the immunohistochemical staining method (p38 MAPK polyclonal antibody, Stressgen) and then observed under a light microscope with 400× magnification. The statistical analysis was performed by using oneway ANOVA to verify the significance of differences between groups, then least significant different (LSD) statistical test was used to verify the significance of differences between each group.

\section{RESULTS}

The expression of p38 MAPK on epithelial cells derived from the tongue of a subject is shown in Fig. 1. The immunosuppressed group (IS) had the lowest expression of p38 MAPK (26.00 \pm 2.32) compared to ISC (26.40 \pm 3.71), ISC+N (34.20 \pm $0.99)$, and ISC+AI (36.05 \pm 1.54$)$, while the highest expression of p38 MAPK appeared in the group of subjects which had been induced with $C$. albicans and treated topically with $20 \%$ A. ilicifolius L. methanolic extract (ISC+AI) compared to other groups (Fig. 2). The data was normally distributed and homogeneous. A one-way ANOVA statistical test was utilised which indicated the significant differences between groups $(p<0.05)$. LSD statistical test confirmed significant differences existed between ISC+AI and ISC $+\mathrm{N}$ to IS and ISC $(p<0.05)$. No significant differences were present between IS and ISC; ISC+AI and ISC $+\mathrm{N}(p>0.05)$.

\section{DISCUSSION}

The cellular signalling mechanisms against microorganism, in particular C. albicans, involve MAPK, nuclear factor kappa-lightchain-enhancer of activated $\mathrm{B}$ cells $(\mathrm{NF}-\kappa \mathrm{B})$ and phosphatidylinositide 3-kinase (PI3K) pathways (Naglik \& Moyes, 2011). MAPK signalling via p38 appears to discriminate between yeast and hyphal cells of $C$. albicans (Mercado et al., 2012). Recognition 

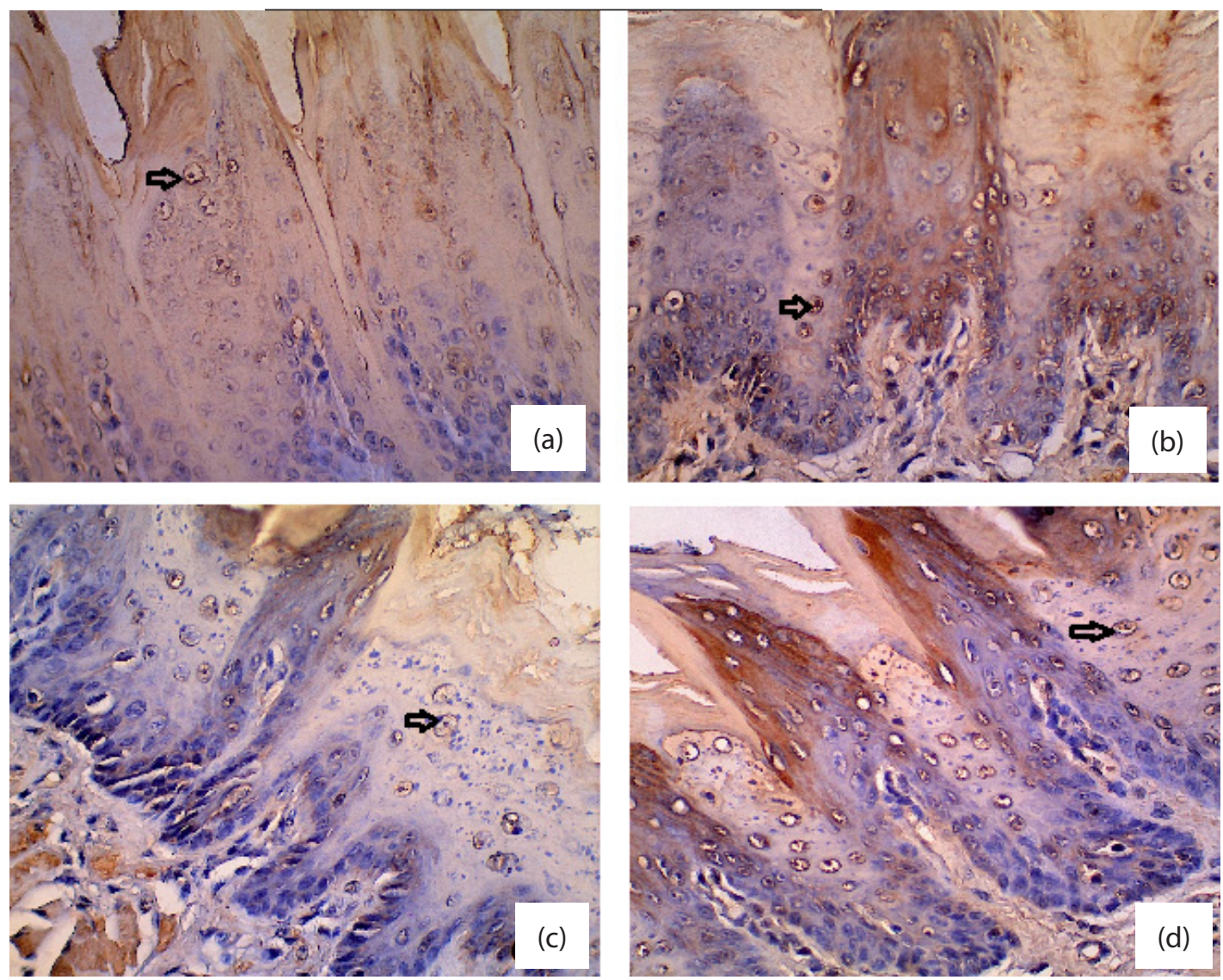

Fig. 1 The p38 MAPK expression on the epithelial cell of the tongue (black arrow). (a) Immunosuppression (IS) group; (b) Immunosuppression with oral candidiasis without treatment (ISC) group; (c) Immunosuppression with oral candidiasis and nystatin treatment (ISC $+\mathrm{N}$ ) group; and (d) Immunosuppression with oral candidiasis and A. ilicifolius L. methanolic extract 20\% treatment (ISC+AI) group (400× magnification).

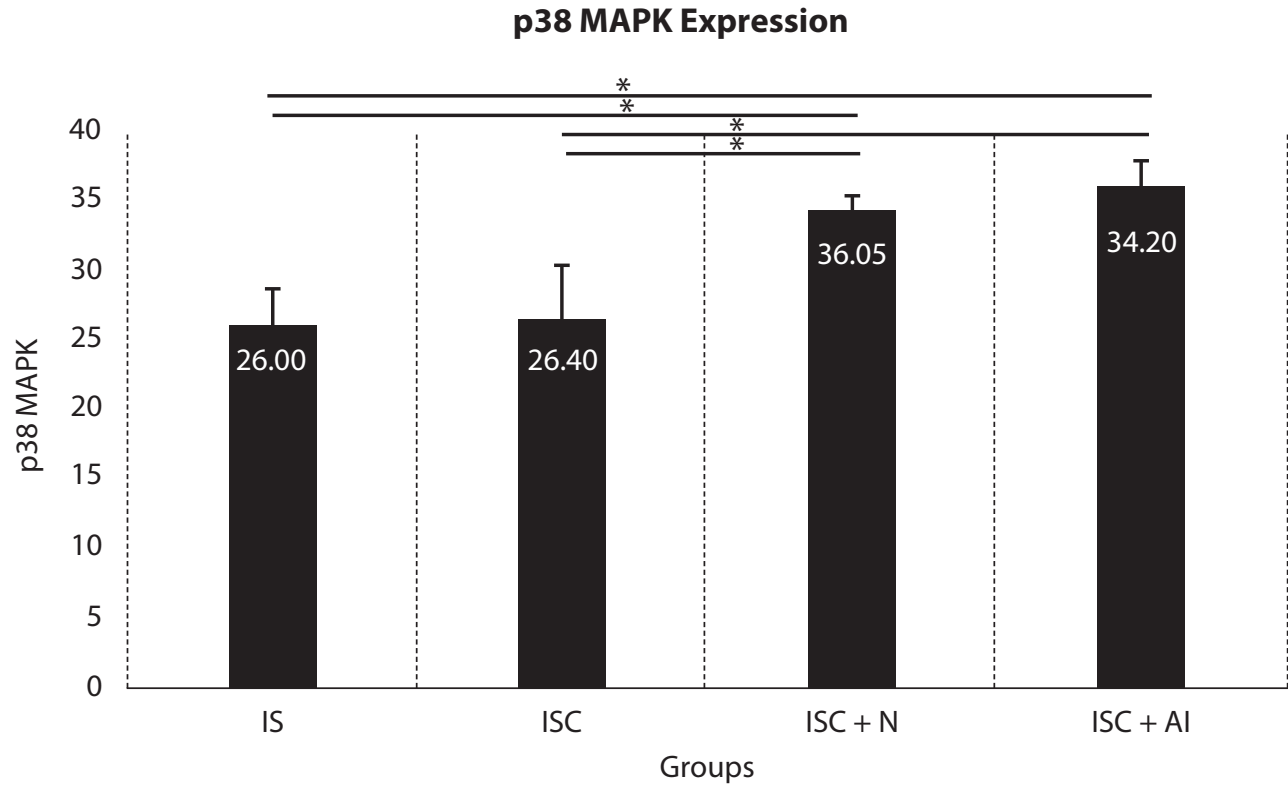

Fig. 2 The means of $\mathrm{p} 38$ MAPK expression on the epithelial cell of the tongue in each group. 
mechanism of $C$. albicans of yeast and hyphal cells can occur via pathogen-associated molecular patterns (PAMPs), e.g., mannans or $\beta$-glucans, and pattern recognition receptors (PRRs), e.g., toll-like receptors (TLR) (Moyes et al., 2010). Recognition via PRRs results to the activation of NF$\kappa \mathrm{B}$, MAPK and PI3K signalling pathways. Signalling MAPK via p38 induced c-Fos transcription factor activation and together with $\mathrm{NF}-\kappa \mathrm{B}$ and PI3K signalling leads to cytokines and inflammatory mediators' productions, consequently activating the immune cells (Naglik \& Moyes, 2011; Tang et al., 2016). The IL-8 recruits neutrophils which is activated by members of the GMCSF, G-CSF, and IL-1 family. Neutrophils protects directly through phagocytosis, and indirectly activates $\mathrm{Th}$, including $\mathrm{Th}-17$ which produces IL-17 and IL-22, that play a role in the protection mechanism against C. albicans (Moyes et al., 2012).

Activation of $\mathrm{p} 38$ MAPK by $C$. albicans hyphae results in the upregulation of proinflammatory cytokines (Tang et al., 2016). The p38 MAPK activation is also known to induce corticosteroid insensitivity. Activation of p38 MAPK can stabilise proinflammatory cytokines and chemokines transcripts (Mercado et al., 2012). In this research, subjects were immunosuppressed through the administering of dexamethasone and combined with tetracycline orally to acquire an environment that supports the occurrence of oral candidiasis. Dexamethasone is one of corticosteroid drug that may affect the p38 MAPK expression.

The level of p38 MAPK expression immunosuppression group with or without oral candidiasis from this research was found similar and tend to be low when compared to the treatment group. Immunosuppression condition by corticosteroid may cause inactivation of the p38 via MAPK phosphatase 1. Glucocorticoid-induced MAPK phosphatase 1 dephosphorylates and inactivates all members of the MAPK family of proteins, including Jun N-terminal kinase, extracellular-signal-related kinase 1 and 2, and p38 kinase (De Bosscher et al., 2003; Rhen \& Cidlowski, 2005). This pathway is one of corticosteroid antiinflammation mechanisms and possibly increase the opportunistic pathogen, C. albicans to develop and invade the host.

The treated oral candidiasis group either nystatin or $A$. ilicifolius L. methanolic extract, the level of p38 MAPK expression was increased compared with the immunosuppression group with or without oral candidiasis. This result indicates that either nystatin or $A$. ilicifolius L. methanolic extract was involved in p38 MAPK activation. Baek et al. (2013) reported that treatment with nystatin resulted in elevated phosphorylation of ERK, p38 MAPK, and $\mathrm{JNK}$, indicating activation of the three MAPKs by nystatin. The presence of nystatin possibly helps to dismiss infection via recruitment of inflammatory cells (Baek et al., 2013). Previous studies have reported that $A$. ilicifolius L. leaves extract could increase the amount of receptor (TLR-2), cytokine proinflammatory (IL-22) and macrophage in oral candidiasis with immunosuppressive condition (Andriani \& Pargaputri, 2018; Andriani \& Pargaputri, 2019; Setyawan et al., 2019). These properties are involved in the defence mechanism against $C$. albicans. The present study also reported a similar effect between the treatment group of nystatin and $A$. ilicifolius L. methanolic extract $20 \%$. Previous studies of both nystatin and $A$. ilicifolius $\mathrm{L}$. extract have similar effect in increasing the amount of TLR2 and IL22 expression in oral candidiasis immunosuppressed conditions models (Andriani \& Pargaputri, 2018; Andriani \& Pargaputri, 2019).

Methanol leaves $A$. ilicifolius L. at a concentration of $20 \%$ has the best antifungal activity (Andriani et al., 2020). This extract contains flavonoid, tannin, steroid, saponin, terpenoid, glycoside and polyphenol (Gayathri \& Gayathri, 2014; Andriani et al., 2020). The 2-Benzoxazolinone (BOA) and benzoxazinoids which presents in methanol 
leaves extract of $A$. ilicifolius L., promote antifungal and antioxidant activity (Saranya et al., 2015). Methanol leaves extract of A. ilicifolius $\mathrm{L}$. have strong antioxidant activity (Avijit et al., 2012; Andriani et al., 2020). Flavonoids and phenolic compounds that were isolated from methanolic leaves extract $A$. ilicifolius $\mathrm{L}$. showed high antioxidant activity in rats. This extract also possessed considerable significant antinociceptive activity on experimental laboratory animals (Saranya et al., 2015).

\section{CONCLUSION}

Methanolic extract $A$. ilicifolius L. treatment could enhance p38 MAPK expression in oral candidiasis with the immunosuppressed condition. Within the limitation of this study, it can be concluded that this extract might work as an antifungal and involved in the MAPK signalling pathway. However, a more in-depth study of this extract is needed, so that it can be used as potential antifungal drugs.

\section{ACKNOWLEDGEMENTS}

The author would like to thank Lembaga Penelitian dan Pengabdian Masyarakat, Universitas Hang Tuah Surabaya for the internal grant (No: S.Gas/003/UHT.C.2/ II/2020) and the students that participated in this study.

\section{REFERENCES}

Adcock IM, Lane SJ (2003). Corticosteroidinsensitive asthma: Molecular mechanisms. f Endocrinol, 178(3): 347-355. https://doi .org/10.1677/joe.0.1780347

Andriani D, Pargaputri AF (2018). The effects of Acanthus ilicifolius chloroform extract on TLR-2 expression of macrophages in oral candidiasis. Maj Kedokt Gigi, 51(4): 205209. https://doi.org/10.20473/j.djmkg.v51 .i4.p205-209
Andriani D, Pargaputri AF (2019). Enhance of IL-22 expression in oral candidasis immunosuppressed model with Acanthus ilicifolius extract therapy. IOP Conf Ser Earth Environ Sci, 217: 012056. https://doi.org/10.1088/1755-1315/217/1/ 012056

Andriani D, Revianti S, Prananingrum W (2020). Identification of compounds isolated from a methanolic extract of Acanthus ilicifolius leaves and evaluation of their antifungal and antioxidant activity. Biodiversitas, 21(6): 2521-2525. https://doi.org/10.13057/biodiv/d210625

Avijit D, Raihan SM, Sariful IHM, Hamiduzzaman M, Monjur-Al-Hossain ASM (2012). Phytochemical screening and the evaluation of the antioxidant, cytotoxic and antimicrobial properties of Acanthus ilicifolius (Family: Acanthaceae). Int Res $\mathcal{F}$ Pharm, 3(8): 153-156.

Baek S, Kim SM, Lee SA, Rhim BY, Eo SK, Kim K (2013). The cholesterol-binding antibiotic nystatin induces expression of macrophage inflammatory protein-1 in macrophages. Biomol Ther (Seoul), 21(1): 42-48. https://doi.org/10.4062/biomolther .2012 .082

Brunke S, Hube B (2013). Two unlike cousins: Candida albicans and C. glabrata infection strategies. Cell Microbiol, 15(5): 701-708. https://doi.org/10.1111/cmi.12091

Chami N, Chami F, Bennis S, Trouillas J, Remmal A (2004). Antifungal treatment with carvacrol and eugenol of oral candidiasis in immunosuppressed rats. Braz F Infect Dis, 8(3): 217-226. https://doi .org/10.1590/S1413-86702004000300005

De Bosscher K, Vanden Berghe W, Haegeman $G$ (2003). The interplay between the glucocorticoid receptor and nuclear factor$\kappa \mathrm{B}$ or activator protein-1: Molecular mechanisms for gene repression. Endocr Rev, 24(4): 488-522. https://doi.org/10 $.1210 / \mathrm{er} .2002-0006$ 
Gayathri GA, Gayathri M (2014). Preliminary qualitative phytochemical screening and in vitro hypoglycemic potential of Acanthus ilicifolius and Evolvulus emerginatus. Int $\mathcal{F}$ Pharm Pharm Sci, 6(6): 362-365.

Hebecker B, Naglik JR, Hube B, Jacobsen ID (2014). Pathogenicity mechanisms and host response during oral Candida albicans infections. Expert Rev Anti Infect Ther, 12(7): 867-879. https://doi.org/10.1586/14 787210.2014 .916210

Kant V, Verma PK, Kumar P (2009). Immunosuppressive drug therapy: An overview. I Immunol Immunopathol, 11(2): 21-32.

Mercado N, Hakim A, Kobayashi Y, Meah S, Usmani OS, Chung KF et al. (2012). Restoration of corticosteroid sensitivity by p38 mitogen activated protein kinase inhibition in peripheral blood mononuclear cells from severe asthma. PLoS One, 7(7): e41582. https://doi.org/10.1371/journal. pone. 0041582

Moyes DL, Murciano C, Runglall M, Kohli A, Islam A, Naglik JR (2012). Activation of $\mathrm{MAPK} / \mathrm{c}-\mathrm{Fos}$ induced responses in oral epithelial cells is specific to Candida albicans and Candida dubliniensis hyphae. Med Microbiol Immunol, 201(1): 93-101. https://doi.org/10.1007/s00430-011-0209-y

Moyes DL, Naglik JR (2011). Mucosal immunity and Candida albicans infection. Clin Dev Immunol, 2011: 346307. https://doi.org/10 $.1155 / 2011 / 346307$

Moyes DL, Runglall M, Murciano C, Shen C, Nayar D, Thavaraj S et al. (2010). A biphasic innate immune MAPK response discriminates between the yeast and hyphal forms of Candida albicans in epithelial cells. Cell Host Microbe, 8(3): 225-235. https://doi.org/10.1016/j.chom.2010.08.002
Naglik JR, Moyes D (2011). Epithelial cell innate response to Candida albicans. Adv Dent Res, 23(1): 50-55. https://doi.org/10 .1177/0022034511399285

Noble SM, Gianetti BA, Witchley JN (2017). Candida albicans cell-type switching and functional plasticity in the mammalian host. Nat Rev Microbiol, 15(2): 96-108. https://doi.org/10.1038/nrmicro.2016.157

Rhen T, Cidlowski JA (2005). Antiinflammatory action of glucocorticoids - New mechanisms for old drugs. N Engl f Med, 353(16): 1711-1723. https://doi.org/10 $.1056 /$ NEJMra050541

Saranya A, Ramanathan T, Kesavanarayanan KS, Adam A (2015). Traditional medicinal uses, chemical constituents and biological activities of a mangrove plant, Acanthus ilicifolius Linn: A brief review. Am Euras $\mathcal{F}$ Agric Environ Sci, 15(2): 243-250. https://doi.org/10.5829/idosi .aejaes.2015.15.2.12529

Setyawan G, Andriani D, Soesilo D (2019). Pengaruh pemberian ekstrak methanol daun Acanthus ilicifolius topikal terhadap jumlah makrofag pada penyembuhan model oral candidiasis dengan kondisi imunosupresi. Denta $\mathcal{f}$ Kedokt Gigi, 13(1): 61-68. https://doi.org/10.30649/denta .$v 13 \mathrm{i} 1.182$

Sofia S, Merlee TMV (2017). Isolation of bioactive compounds by GC-MS and biological potentials of Acanthus ilicifolius, L. Int Res J Biol Sci, 6(6): 7-19.

Tang SX, Moyes DL, Richardson JP, Blagojevic M, Naglik JR (2016). Epithelial discrimination of commensal and pathogenic Candida albicans. Oral Dis, 22(Suppl 1): 114-119. https://doi .org/10.1111/odi.12395 
Wächtler B, Wilson D, Haedicke K, Dalle F, Hube B (2011). From attachment to damage: Defined genes of Candida albicans mediate adhesion, invasion and damage during interaction with oral epithelial cells. PLoS One, 6(2): e17046. https://doi .org/10.1371/journal.pone.0017046
Zakikhany K, Naglik JR, Schmidt-Westhausen A, Holland G, Schaller M, Hube B (2007). In vivo transcript profiling of Candida albicans identifies a gene essential for interepithelial dissemination. Cell Microbiol, 9(12): 29382954. https://doi.org/10.1111/j.1462-5822 $.2007 .01009 . \mathrm{x}$ 